DOI 10.18551/rjoas.2020-08.18

\title{
ENVIRONMENTAL IMPACT RESULTING FROM ASPHALT MIXING PLANT'S ACTIVITIES AT GROGOL, KEDIRI
}

\author{
Romadhon*, Student \\ Doctoral Study Program of Environmental Sciences, University of Brawijaya, Indonesia
}

Fanani Z., Wicaksono A., Kurniawan A., Lecturers

University of Brawijaya, Indonesia

*E-mail: Ir.romadhon@yahoo.com

\begin{abstract}
This study aims at analyzing the environmental impact resulting from Asphalt Mixing Plant (AMP) activities at Grogol, Kediri. This study used a mixed research method consisting of a survey and case study. In addition, the research site took place at Grogol, Kediri. Data were collected through interviews, scales, observation and documentation. Next, the data were analyzed using Structural Equation Modeling (SEM) Analysis and Qualitative Data Analysis. The study results showed that the value of T-statistics of a relationship between the Air Pollution Impact producing from AMP Engine Activities and Air Quality was 23,882 > 1.96. It means there is a significant effect of Air Pollution Impacts producing from AMP Engine Activity on Air Quality. As for the environmental impact resulting from AMP activities in Grogol, Kediri, were air pollution, an increase of noise, a decrease of public and employee health, road damage, and potential fire hazards. The impact was mostly felt by the community within a radius of $<500 \mathrm{~m}$ to $2 \mathrm{~km}$, in which there were six affected villages. Therefore, the supervision system for industrial waste management, especially AMP waste causing air pollution, must experience systematic and periodic monitoring by the Environmental Agency.
\end{abstract}

\section{KEY WORDS}

Environmental impact, asphalt mixing plant, local policy, monitoring.

Infrastructure development is one of the national development priorities. Every planned policy related to the development must aim at an equitable development throughout Indonesia, and it must be carried out on the basis of community interests. Therefore, it can have an impact on the refinement and improvement of the living standard of the Indonesian people. Essential components in the development aspects include: (1) economic development; (2) environmental development; (3) institutional development; and (4) physical and social development (Adisasmita, 2013: 35). Based on the aforementioned four components, the infrastructure development is included in the form of physical development. The existence of good infrastructure has an important role in supporting the fulfillment of basic community rights like food, clothing, housing, education and health. Hence, the infrastructure is a capital needed by the community to support activities in various fields.

The policy of Indonesian Government is currently focused on the importance of carrying out the sustainable and environmentally friendly infrastructure development promoting the nature conservation principles. According to Salim in Brata (1992), sustainable development is a development process optimizing the advantages of natural and human resources by harmonizing natural and human resources within development. The need for the sustainable development concept is based on five primary ideas. First, the sustainable process must take place successively, constantly and continuously, which is supported by natural resources, environmental and human quality developing continuously as well. Second, natural resources (especially air, water, and land) have a threshold, where their use will reduce the quantity and quality. Third, the environmental quality is directly correlated with quality of life. Fourth, the current pattern of natural resource use should not exclude the 
possibility of choosing other options in the future. The last, fifth, sustainable development relies on trans-generational solidarity. These five principles are adopted and developed by the World Commission on Environment and Development. Accordingly, the concept of sustainable development does imply limits or carrying capacity of the environment.

Through Sustainable Development Goals (SDGs), the goal of the development plan is to sustain the human life and the environment. Therefore, the aim of Government of Indonesia is to respond to the development goals set by the SDGs. The Sustainable Development Goals (SDGs) are implemented through Presidential Regulation No. 59 of 2017 concerning the Implementation of Achieving Sustainable Development Goals. With the enactment of these development goals, there still possibly are obstacles and challenges to be faced in the future. In the implementation, the obstacles and challenges faced are inclusive principles ensured in their application and no one left behind, arranging and developing a structured, systematic, connected and integrated data collection system in all programs made by stakeholders. Consequently, the SDGs goals can be achieved in accordance with the global mandate and goals of reducing/eliminating poverty, protecting the earth, and ensuring peace and prosperity for every human being.

For developing countries like Indonesia, infrastructure development is one of the necessary prerequisites that must be met to increase economic growth. On that account, infrastructure development must also pay attention to the principles of environmental preservation based on the concepts of green infrastructure and green economy. Vaugh and Pollard (2003) stated that, generally, infrastructure includes roads, bridges, water and sewage systems, airports, ports, public buildings including schools, health facilities, prisons, recreation, power plants, security, fire station, landfills garbage and communication (lek, 2013: 31).

One of the infrastructure developments having high urgency is the physical development of road facilities The commitment manifestation of the Provincial Government of East Java in carrying out infrastructure development in the form of roads is outlined in the vision for development of East Java in the period of 2014 to 2019, which is: "Jawa Timur Lebih Sejahtera, Berkeadilan, Mandiri, Berdaya Saing, and Berakhlak" (East Java is more prosperous, fair, independent, competitive, and morally superior). To realize the vision of development in East Java in the period of 2014-2019, the provincial government focuses on promoting sustainable development and spatial planning related to the existed third mission. It means that, in the third mission, the physical infrastructure development which is in the form of roads as transportation infrastructure must refer to spatial planning, integrate to national transportation systems and meet the road safety standards, and be environmentally sound. Road infrastructure development built will bring many long-term advantages, especially in creating economic connectivity in term of industrial growth. Like a coin consisting of two sides, the development and growth of the industry brings positive advantages and negative impacts. Positive advantages of the development and growth of the industrial sector are the more jobs opportunity, the increase of the community income and so forth. On the other hand, it turns out that progress in the industrial sector suffers a negative impact, especially on the environment. The impact is the rampant pollution and environmental destruction by those companies.

It is as with the Asphalt Mixing Plant (AMP) Activity in Grogol, Kediri. It operates as a road infrastructure development industry. Undoubtedly, it allows the potential for environmental impacts that can result in not achieving sustainable development goals. Therefore, the formulated research question in this study is: how the effect of the Asphalt Mixing Plant (AMP) activities in Grogol, Kediri on the environment is. The study aim at analyzing the environmental impacts resulting from the Asphalt Mixing Plant (AMP) activities in Grogol, Kediri, by knowing what impacts are emerged, thus they can then be used as a reference to determine steps to minimize the negative impacts of industrial activities arising, especially in the environmental institution like a supervisor, controller and implementer institution in the achievement of sustainable development and the sustainable living environment. 


\section{METHODS OF RESEARCH}

This study uses a mixed methodology. According to Creswell (2014), a mixed-method refers to "a methodology that provides philosophical assumptions in showing direction or giving instructions on how to collect and analyze data as well as the combination of quantitative and qualitative approaches through several phases of the research process. This research uses a gradual mixture technique. This strategy can be done by interviewing to get qualitative data and then, quantitative data. In this study, it used a survey and case study.

Data collection was carried out using interviews, scale, observation, and documentation. The data were collected through direct measurements of informants of the AMP factory management in Bakalan Village, Grogol Subdistrict, Kediri Regency, local communities around the factory, Local Government of Kediri Regency, and Village Government.

Data analysis and interpretation methods used are SEM (Structural Equation Modeling) and Qualitative Data Analysis. SEM is a multivariate analysis that can analyze variable relationships in a complex way. SEM is able to explain the relationships between variables in the exogenous and endogenous latent variables in the study. The second analysis is a qualitative data analysis aims at organizing the data and then reduce the data into a unit that can be managed, as well as finding and confronting the environmental impacts resulting from the Asphatl Mixing Plant (AMP) activities in Bakalan, Grogol, Kediri.

\section{RESULTS AND DISCUSSION}

Based on the study results, the path diagram conversion into the measurement model can be recognized through an explanation of the Measurement Model of Air Pollution Impact Variable on AMP Machine Activities. Measurement Indicators of the air pollution impacts variables on AMP engine activities (X1) can be seen through the table below:

Table 1 - Measurement Indicators of the air pollution impacts variables on AMP engine activities (X1)

\begin{tabular}{|c|c|c|}
\hline Variable & Indicator & Loading Indicator \\
\hline \multirow{3}{*}{ Air pollution impacts on AMP engine activities } & $\mathrm{X} 1.1$ & 0.858 \\
\cline { 2 - 3 } & $\mathrm{X} 1.2$ & 0.797 \\
\cline { 2 - 3 } & $\mathrm{X} 1.3$ & 0.717 \\
\cline { 2 - 3 } & $\mathrm{X} 1.4$ & 0.849 \\
\hline
\end{tabular}

Based on the measurement model aforementioned, it is perceived that the indicator loading value of a decline in the environmental conditions of the community (X1.1) is 0.858 . It means that the diversity of air pollution impact variables on AMP engine activities (X1) can be explained by an indicator of a decrease in the environmental conditions of the community (X1.1) of $85.8 \%$. Put differently, the contribution of the indicator of a decline in the environmental conditions of the community (X1.1) in measuring the air pollution impact variable on AMP engine activities (X1) was $85.8 \%$. Next, the indicator loading value of a decrease in plant fertility (X1.2) was 0.797 . It means that the variable variability of air pollution impact on AMP engine activities (X1) can be explained by an indicator of a decrease in plant fertility (X1.2) of $79.7 \%$. In other words, the contribution of the indicator of a decrease in plant fertility (X1.2) in measuring the air pollution impact variable on AMP engine activities (X1) was 79.7\%. Afterwards, the indicator loading value of noises around the house/environment $(\mathrm{X} 1.3)$ was 0.717 . It means that the diversity of air pollution impact variables on AMP engine activities (X1) can be explained by the noise indicator around the house/environment (X1.3) of $71.7 \%$. Express differently, the contribution of noise indicators around the house/environment (X1.3) in measuring the air pollution impact variables on AMP engine activities (X1) was $71.7 \%$.

Furthermore, the indicator loading value of a decline in public health (X1.4) was $0.849 \%$. It means that the variable variability of air pollution impact on AMP engine activities (X1) can be explained by an indicator of a decline in public health (X1.4) of $84.9 \%$. In other 
words, the contribution of the indicator of a decline in public health (X1.4) in measuring the air pollution impact variable on AMP engine activities (X1) of $84.9 \%$. The measurement model of organizational commitment variables also informed that the indicator of a decline in the environmental conditions of the community (X1.1) has the greatest loading value. It means that the indicator of a decline in the environmental conditions of the community (X1.1) was the most dominant indicator in measuring the air pollution impact variable on AMP engine activities (X1).

Subsequently, based on the value of Hypothesis testing of the effect of Air Pollution Impact toward AMP Machine Activities on Air Quality, it is identified that the value of Tstatistics of the relationship between the Air Pollution Impact toward AMP Machine Activities on Air Quality is 23,882 . The test results showed that the value of T-statistics was $>1.96$. It means there is a significant effect of the Air Pollution Impact toward AMP Machine Activities on Air Quality.

Based on the path diagram conversion in the structural model, measurement is intended to determine the effect directly or indirectly. As for the direct and indirect model effects, they are presented in the following table:

Table 2 - Converting Path Diagrams into Structure Models

\begin{tabular}{|c|c|c|c|c|c|}
\hline Exogenous & Endogenous & Intervening & $\begin{array}{c}\text { Direct } \\
\text { Coefficient }\end{array}$ & $\begin{array}{c}\text { Indirect } \\
\text { Coefficient }\end{array}$ & Total \\
\hline $\begin{array}{c}\text { Air pollution impacts } \\
\text { on AMP engine } \\
\text { activities }\end{array}$ & Air quality & - & -0.648 & - & - \\
\hline $\begin{array}{c}\text { Air pollution impacts } \\
\text { on AMP engine } \\
\text { activities }\end{array}$ & $\begin{array}{c}\text { Mitigation Strategy Model of Air } \\
\text { Pollution Resulting from AMP } \\
\text { Engine Activities }\end{array}$ & - & 0.093 & - & $0,098^{*}$ \\
\hline
\end{tabular}

Based on the table above, it can be seen that the structural model formed is Equation $1: Y 1=-0,648 X 1$. It means the direct effect coefficient of air pollution impact toward AMP engine activities on air quality is $-0,648$ stating that the air pollution impact on AMP engine activities has a negative and significant effect on air quality. It means that the greater the impact of air pollution on AMP engine activities, the lower the air quality will be. Then, the equation 2: Y2 $=0,093 \times 1$. It means that the direct effect coefficient of air pollution impact on AMP engine activity toward the mitigation strategy model of air pollution resulting from AMP engine activities showing 0.093 stating the air pollution impact on AMP engine activities has a positive and significant effect on the mitigation strategy model of air pollution resulting from AMP engine activities. It means that the greater the air pollution impact on AMP engine activity, the more the improvement of the mitigation strategy model of air pollution resulting from AMP engine activities.

Environmental Impacts caused by Air Pollution resulting from AMP Activities in Grogo, Kediri. The AMP activities carried out by PT Triple S Putra Kediri produce environmental impacts. According Soemarwoto (1997: 38) defined the impact as a change occurring due to natural activities, both chemical, physical and biological activities. Therefore, the environmental impact caused by AMP activities is an environmental change occurring due to natural AMP activities, both chemical, physical or biological activities. The specification of activities delivering an environmental impact is more focused on the construction and operational stages of AMP performance. Environmental impacts occurred are more on air pollution. At the construction stage of the AMP performance having an impact on the environment in the form of air pollution, there are two activities, including:

1. Activities of Equipment Mobilization and Demobilization, as well as Material Mobilization.

In the activities of equipment mobilization and demobilization, as well as material mobilization, there are negative impacts on the environment, including a decrease in air quality, an increase in noises, a decrease in public health, and road damage. The decrease in air quality occurs because the equipment mobilization is carried out at the same time, resulting in an increase of dust content in the air and $\mathrm{CO}_{2}$ emissions from the transportation 
of equipment and materials for construction. Equipment mobilization at the same time is also producing an increase of noise. In addition, the increase in noises is also undergone from the transportation activities or passing vehicles transporting material and loading and unloading of the material itself.

The continued impact of rising levels of dust and $\mathrm{CO}$ in the air, as well as noise, will affect public health. The decline in air quality due to various pollutants, dust and noise will trigger discomfort and disrupt the health of the surrounding community, especially respiratory disorders. In addition, the increase of transportation vehicles mobilization for material also causes road damage if it exceeds the specified tonnage.

2. Activities of Building Structure Construction.

The impact caused by the building structures construction is a decrease in air quality, an increase in noise and comfort disturbance of the surrounding community. Construction activities using equipment like mixer truck can increase noise. Meantime, the decline in air quality occurs due to dust from building materials, so that the subsequent impact is the comfort disturbance of the surrounding community, especially those having houses with a distance of about.

Based on the specification of activities producing an environmental impact caused by construction and operational activities, the AMP performance can be constructed into several points experienced by the community in the area around the factory site, including:

3. Air pollution.

Decree issued by Minister of Population and Environment Number 2/MENKLH/1988 explains that pollution is the entry of living things, substances, energy and/or other components into water/air, and/or the changes in the composition of water/air by human activities or natural process. According to Daldjoeni (2003: 122), air pollution types are grouped into two. They are air pollution caused by different types of industries and differences in the composition or concentration of the pollution elements. In the activities of AMP operational, this form of air pollution occurs due to the emergence of dust particles and the decrease of air quality.

The existence of PT Triple S Putra Kediri has an impact on air pollution. It can be perceived from the air condition in six villages, Bakalan, Grogol, Datengan, Sonorejo, and Sendang, around the factory experiencing the changes in air condition before and after the factory establishment. The study results showed that the air condition changes to be polluted. It is indicated by the indicator of dust particulates showing as much as $91.1 \%$. This condition is exacerbated by weather conditions that can affect air pollution. Because if the weather is hot and windy in the dry season, it will worsen the condition. It is because dust particles carried by wind and in hotter temperature will extend more and more range. It is indicated by the achievement of the weather conditions indicator affecting the air pollution form by $76.8 \%$.

The air pollution impact can also be known through indicators of a decline in environmental conditions and a decrease in plant fertility. Indicator of a decline in environmental conditions of the community (X1.1) by $85.8 \%$ and indicators of a decrease in plant fertility (X1.2) by $79.7 \%$. The air pollution impact is generally experienced by people living between distances $<500 \mathrm{~m}$ to $2 \mathrm{Km}$ from the industrial site. The occurrence of air pollution can be noted from the presence of black dust clinging to the leaves of trees and attached to the building that is bustling around the industrial site.

The air pollution occurring was essentially included in the category of mild impact because most respondents only experienced dust sticking to the leaves of trees and buildings around the industry. In addition, the only community experiencing the impact was those residing at a radius of $<500 \mathrm{~m}$ to $2 \mathrm{~km}$ from the industrial site. Thus, PT Triple S Putra Kediri needs to make an effort to manage the impact by carrying out tree planting in the industrial site. These efforts are considered as an effective way in reducing the impact of air pollution because trees can absorb $\mathrm{CO}_{2}$. Therefore, it can reduce the number of pollutants in the air. Dust and air quality levels $\left(\mathrm{SO}_{2}, \mathrm{CO}, \mathrm{NOx}, \mathrm{O}_{3}\right.$, dust, Lead, $\mathrm{H}_{2} \mathrm{~S}$, Ammonia, Hydrocarbons) must not exceed the Quality Standards in accordance with Governor 
Regulation of East Java No. 10/2009 concerning Standards of Air Quality and Emission resulting from Unmoving Source in East Java.

Noise resulting from activities performed by PT Triple S Putra Kediri is caused by the vehicles mobilization (transportation vehicles and mixer truck) and the AMP machine activities. The values of noise should not exceed the Decree issued by Minister of Environment No. 48 of 1996 Concerning Noise Quality Standards, which is the noise level of $70 \mathrm{~dB}(\mathrm{~A})$ for dust areas. Generally, Noise impacts have not had a severe impact, because the majority of respondents did not experience a disturbance, and only respondents residing from the location of the factory between a radius of $<500 \mathrm{~m}-2 \mathrm{~km}$ experienced the impact of noise. In addition, the time and intensity of noise solely occur at certain times, which is during the vehicle mobilization schedule (transport vehicles and mixer truck) and the AMP machine activities. Therefore, the impact of perceived noise is not a severe impact. However, this condition can also disturb the comfort of the surrounding community. Thus, PT Triple S Putra Kediri has a policy not to operate AMP machines during the rest time of the community.

The impact on environmental conditions toward the existence of PT Triple S Putra Kediri can cause the disturbance of the community comfort. It is because it can lead to environmental degradation and a decrease in public health level. The decline in public health and employees as a consequence of air pollution and the increase of noise. As many as $84.9 \%$ of respondents stated the air pollution impact on AMP engine activities resulted in a decline in public health. Based on the results of a research conducted by Djayanti (2012: 107), she found that air pollution caused by industrial activities contributes hazardous gases like sulfur dioxide $\left(\mathrm{SO}_{2}\right)$, nitrogen dioxide $\left(\mathrm{NO}_{2}\right)$, hydrocarbons $(\mathrm{HC})$, carbon monoxide $(\mathrm{CO})$ and dust. The air pollution not only threatens environmental sustainability, but also has a negative impact on human health and well-being.

According to Chadra (2006), the effects of air pollution on human health can be seen both rapidly and slowly. The rapid effect experienced from air pollution is based on the results of epidemiological studies showing that a sudden increase in cases of air pollution will also increase the number of cases of morbidity and mortality due to respiratory tract diseases. In certain situations, $\mathrm{CO}$ gas can cause sudden death because the CO gas affinity for blood hemoglobin (becoming met-hemoglobin) is stronger than $\mathrm{O} 2$ affinity power, so that there is a lack of oxygen gas in the body. Meanwhile, the slow effect of air pollution is thought to be one of the causes of chronic bronchitis and primary lung cancer. Diseases caused by air pollution include Lung emphysema, Black lung disease, Asbestosis, Silicosis, Bisinosis, and asthma suffered by children.

The damage level to roads traversed by heavy equipment and hauling truck mobilization carrying material from the delivery site to the location of construction service activities. Thus, to minimize the occurrence of road damage, an overload arrangement must be made to the vehicle tonnage according to the road class. In addition, if road damage occurs, an immediately restoration to the road is carried out in coordination with the agency of Public Works, Public Housing and Copyright of Kediri.

The magnitude of the potential for fire hazard is caused by the storage of flammable raw materials (asphalt and diesel) which are easily to be burn when there is a fire source. Besides, the potential for fire hazards can also occur from misuse or failed operation of the generator engine. Therefore, the efforts needed to be made are to minimize the potential for fire hazards, which is by providing the fire extinguisher with the required number of fire extinguishers, in which every fire extinguisher is for $400 \mathrm{~m} 2$ in accordance with the Ministerial Regulation of the Minister of Manpower and Transmigration No. PER-04/MEN/1980 concerning The Terms of Installation and Maintenance of Fire Extinguishers. In addition, the person in charge of PT Triple S Putra Kediri must also provide special signs to prevent fires, as well as provide a fire alarm system at the activity site in sufficient numbers and accordance with applicable requirements. Regular simulations or exercises on fire prevention and control also need to be carried out for each worker.

The magnitude of the impact of B3 waste is based on the amount of sludge in the storage tank of produced asphalt and diesel fuel. Thus, the required effort in minimizing this B3 waste is by using the used sludge into the drum, specifically for storage tanks of asphalt 
and diesel fuel. Then, the drum is put into a temporary B3 Waste Storage Facility meeting the textual specifications including a waterproof floor, $1 \%$ slope, a drainage system, a dike, a spill container, an emergency response equipment like fire extinguisher and sand to cope with the spilled sludge from storage tank of asphalt and diesel fuel. However, the most substantial thing must be done by the person in charge of PT Triple S Putra Kediri is to apply for a permission of temporary storage for B3 waste to the Environmental Agency of Kediri, especially sludge for storage tank of asphalt and diesel. It also can cooperate with third parties having permission to operate and/or manage used oil.

\section{CONCLUSION}

As for the environmental impact resulting from AMP activities PT Triple S, Kediri, were air pollution, an increase of noise, a decrease of public and employee health, road damage, and potential fire hazards. The impact was most experienced by the community within a radius of $<500 \mathrm{~m}-2 \mathrm{~km}$, which is in six affected villages, Bakalan, Grogol, Datengan, Sonorejo, Wonoasri, and Sendang. Then, from the PLS analysis having been done, it can be seen that the factors affecting air quality in Grogol, Kediri (Y1) are AMP activities (X1), air pollution (X2), and the impact of air pollution on AMP machine activities (X1) of $70.1 \%$, while the remaining $29.9 \%$ is contributed by other variables not discussed in this study. Of the three factors, the most factor influencing air quality in Grogol, Kediri, is the impact of air pollution on AMP engine activities (X1). The impact of air pollution on AMP engine activities is directly related to air quality in Grogol, Kediri. Supervision systems for industrial waste management, especially AMP waste causing air pollution, must receive continual and periodic monitoring by the Environmental Agency of Kediri.

\section{REFERENCES}

1. Adisasmita, Rahardjo, 2013. Teori-Teori Pembangunan Ekonomi. Yogyakarta: Graha IImu.

2. Brata, Suwandi S., 1992. Pembangunan Berkelanjutan: Mencari Format Politik. Jakarta: PT. Gramedia Pustaka Utama.

3. Peraturan Presiden Nomor 59 Tahun 2017 tentang Pelaksanaan Pencapaian Tujuan Pembangunan Berkelanjutan.

4. Lek, Mesak., 2013. "Analisis dampak pembangunan jalan terhadap pertumbuhan usaha ekonomi rakyat di pedalaman May Brat Provinsi Papua Barat (Studi kasus di Distrik Ayamaru, Aitinyo and Aifat)". Dalam Open Journal Systems, 6:11, 2013.

5. Creswell, John W., 2010. Research design: pendekatan kualitatif, kuantitatif, and mixed. Yogjakarta: PT Pustaka Pelajar.

6. Soemarwoto, Otto. 1997. Ekologi, LingkunganHidup and Pembangunan. Jakarta: Djambatan.

7. Keputusan Menteri Negara Kependudukan and Lingkungan Hidup No. 2/MENKLH/1988.

8. Daldjoeni, N. 2003. Geografi Kota and Desa. Bandung: PT. Alumni.

9. Keputusan Menteri Lingkungan Hidup Nomor 48 Tahun 1996 Tentang Baku Tingkat Kebisingan.

10. Chandra, B, 2006. Pengantar Kesehatan Lingkungan. Jakarta: EGC.

11. Djayanti. Silvy. 2012. Perancangan Prototipe Alat Pengendalian Pencemaran SO2 and NO2 Dengan Teknologi Non Thermal Plasma. Jurnal Riset BBTPPI 2 (Desember 2012), 106-111.

12. Peraturan Menteri Tenaga Kerja and Transmigrasi Nomor PER-04/MEN/1980 tentang Syarat-Syarat Pemasangan and Pemeliharaan Alat Pemadam Api Ringan. 